\begin{tabular}{lc} 
Sharif University of Technology \\
Scientia Iranica \\
SCIENTIA & Transactions B: Mechanical Engineering \\
IRAN ICA & www.scientiairanica.com \\
\hline
\end{tabular}

\title{
An alternative boom design and welding technique to minimize energy consumption during boom production
}

\author{
M. Özcan ${ }^{\mathrm{a}}$, M. Yağci ${ }^{\mathrm{a}, *}$ and V. Alver ${ }^{\mathrm{b}}$ \\ a. Faculty of Engineering and Architecture, Department of Electrical and Electronics Engineering, Necmettin Erbakan University, \\ 42060, Konya, Turkey. \\ b. MPG Makine Prodüksiyon Grubu Research Engineer, Konya, Turkey.
}

Received 15 September 2015; received in revised form 3 June 2016; accepted 5 December 2016

\section{KEYWORDS}

Energy saving;

Global warming;

Welding;

Metal bending;

Welding oscillator.

\begin{abstract}
This paper presents an alternative boom design for mobile cranes and a method to produce it for minimizing the energy consumption during its production. The main change in the production of the crane booms is the shape of the booms. Normally, two symmetric boom parts are manufactured and, then, these parts are welded by two welding processes. In the proposed design, only one part is manufactured and bended at first. Therefore, one welding will be sufficient and a more energy-friendly process is achieved. With the proposed shape, the corner joints are eliminated when forming the boom shape, without any need to produce them beforehand. Single welding process is applied to minimize energy consumption during the manufacturing of the boom; thus, the welding quality becomes more important. In order to satisfy the welding quality, a welding manipulator is designed and manufactured. By using this welding manipulator, used in a closed area, and the applied filter devices, the harmful gases are not released to the operator and the environment. Finally, the energy and time required during the plasmacutting process of boom parts are decreased by about $41 \%$ and the energy consumption during the welding process is decreased by about $53 \%$ compared to the traditional methods.
\end{abstract}

(C) 2017 Sharif University of Technology. All rights reserved.

\section{Introduction}

Production of hazardous gases, mainly $\mathrm{CO}_{2}, \mathrm{SO}_{2}$, and $\mathrm{NO}_{x}$, is one of the main reasons of global warming, which is one of the most important environmental problems of our time [1-5]. In addition to global warming, the gases released into the atmosphere cause a disruption in ecological balance, which is considered to be one of the most serious problems. Global warming is increasing due to the increased energy consumption

*. Corresponding author. Tel.: +90 3323252024 E-mail addresses: mozcan@konya.edu.tr (M. Özcan); valver@kombassan.com.tr (V.Alver) day by day. On average, for each $1 \mathrm{kWh}$ of energy produced by a coal power plant, approximately $1 \mathrm{~kg}$ of $\mathrm{CO}_{2}$ is released to the atmosphere [6-8]. For this reason, it is essential to use energy in the most efficient way and to minimize the production of these gases. Nowadays, two very important research topics are minimization of energy consumption and production of such gases by creating alternative solutions $[9,10]$.

Mobile cranes perform useful material-handling services around the world. They are commonly used for carrying, uploading, and downloading of industrial materials. One of the most important parts of the mobile cranes is booms, which are used for carrying the loads. Moreover, the flexible shape of mobile cranes provides them with efficiency and safety.

In this paper, an alternative boom design tech- 
nique to minimize the energy consumption and hazardous gas formation during the production of booms for mobile cranes is searched. Due to the complexity and high price of the large-volume metal production process, different metal pieces are jointed using a variety of welding methods [11-14]. Some welding methods applied in industrial purposes are corner joints, edge joints, lap joints, T-joints, and butt joints [15].

Laser welding method provides the best performance, but with low efficiency value; therefore, to reduce energy consumption and increase the efficiency, traditional welding methods such as arc welding are commonly preferred for joining metal pieces in the industry, especially in the manufacturing industry for joining the metal pieces thicker than $10 \mathrm{~mm}$ as it requires a vast amount of material and electricity [16].

Arc welding is the most widely used classical welding method and it has been used in the industry for a very long time [17]. The major advantages of the arc welding method are its non-complexity, low cost, flexibility for different purposes in jointing the metal pieces, and continuous integration due to technological improvements [18]. Because of these advantages, this welding method is still used in today's production processes; even it can be adapted to the automation technology [19-21]. The arc welding method can be applied as well with a welding oscillator instead of a manual operator due to continuous improvements in the automated processes. The experience and performance of the operator have a high impact on the quality of the manually performed welding processes. Using the welding oscillator has many advantages such as high quality welding performance, reduced production time and cost of labor, possibility of performing variant welding shapes that are not possible to fulfill by an operator, minimization of errors on the operator's side, and the lowest risk of work accidents [18].

Konya, located in Turkey, can be considered as the center for mobile crane manufacturing companies. These companies use the traditional boom manufacturing techniques such as jointing two steel pieces with two welding operations performed by an operator or using robotic manipulator. These traditional techniques necessitate four corner joint creation steps before welding the two metal pieces.

In the proposed alternative technique (patent pending), only one metal piece is bended to form the boom shape. The main advantage of this technique is decrease in the number of welding steps from two to one. However, in addition to this obvious advantage, the second advantage of this technique is the elimination of the corner joint steps as corner joints are formed naturally while bending the metal pieces.

One single welding step necessitates a high quality welding. In order to ensure the quality of the welding process, we have designed and manufactured a specific welding manipulator [18]. With the help of this manipulator, a high quality and automated welding process is achieved, which also helps to minimize the risks of the manual operation mistakes for the human safety and environmental protection [18,21,22].

The rest of the article is organized as follows: Section 2 explains the alternative boom design and Section 3 gives the details of the design of the welding manipulator. Results and discussions are given in Section 4, and Section 5 provides the conclusions.

\section{Alternative boom design}

Traditionally, booms for mobile cranes are manufactured by jointing two steel pieces with two welding operations performed by an operator. In this traditional technique, two steel pieces with appropriate dimensions are plasma-cut from the steel plate at first. Table 1 lists the details of this cutting step, taking a knuckle boom mobile crane as an example, which has 33 ton-meter

Table 1. Cutting data of the plate S690QL due to lower-upper pieces sizes of booms.

\begin{tabular}{lcccccc}
\hline $\begin{array}{l}\text { Welded } \\
\text { booms }\end{array}$ & $\begin{array}{c}\text { Thickness } \\
(\mathbf{m m})\end{array}$ & $\begin{array}{c}\text { Width } \\
\mathbf{( m m})\end{array}$ & $\begin{array}{c}\text { Length } \\
\mathbf{( m m})\end{array}$ & $\begin{array}{c}\text { Plasma } \\
\text { speed } \\
(\mathbf{m m} / \mathbf{m i n})\end{array}$ & $\begin{array}{c}\text { Plasma } \\
\text { time* } \\
\mathbf{( s )}\end{array}$ & $\begin{array}{c}\text { Consumed } \\
\text { energy** } \\
\mathbf{( k W h )}\end{array}$ \\
\hline Knuckle boom & 10 & 840 & 2650 & 2600 & 162 & 1,3500 \\
1. Extension & 10 & 775 & 2750 & 2600 & 164 & 1,3667 \\
2. Extension & 10 & 715 & 2850 & 2600 & 165 & 1,3750 \\
3. Extension & 10 & 650 & 2950 & 2600 & 167 & 1,3917 \\
4. Extension & 8 & 600 & 3050 & 3300 & 135 & 1,1250 \\
5. Extension & 8 & 545 & 3150 & 3300 & 136 & 1,1334 \\
6. Extension & 8 & 500 & 3250 & 3300 & 138 & 1,1500 \\
\hline
\end{tabular}


Table 2. The mechanical properties of the used quenched and tempered structural steel, S690QL (Steel Number: $1.8931)[23]$.

\begin{tabular}{llll}
\hline \multicolumn{1}{c}{ Designation } & \multicolumn{3}{c}{ Mechanical properties (at 20 ${ }^{\circ}$ C) } \\
\hline Nominal thickness (mm) & $\geq 3 \leq 50$ & $\geq 50 \leq 100$ & $\geq 100 \leq 150$ \\
Yield strength Reh. (MPa, Min.) & 690 & 650 & 630 \\
Tensile strength Rm. (MPa) & $770 / 940$ & $760 / 930$ & $710 / 900$ \\
Min.\% elongation after fracture & 14 & 14 & 14 \\
\hline
\end{tabular}

Table 3. The chemical composition of the used quenched and tempered structural steel, S690QL [23].

\begin{tabular}{cccccc}
\hline Element & Percentage & Element & Percentage & Element & Percentage \\
\hline $\mathrm{C}$ & 0.20 & $\mathrm{~N}$ & 0.015 & $\mathrm{Nb}^{*}$ & 0.06 \\
$\mathrm{Si}$ & 0.80 & $\mathrm{~B}$ & 0.0050 & $\mathrm{Ni}$ & 2.0 \\
$\mathrm{Mn}$ & 1.70 & $\mathrm{Cr}$ & 1.50 & $\mathrm{Ti}^{*}$ & 0.05 \\
$\mathrm{P}$ & 0.025 & $\mathrm{Cu}$ & 0.50 & $\mathrm{~V}^{*}$ & 0.12 \\
$\mathrm{~S}$ & 0.015 & $\mathrm{Mo}$ & 0.70 & $\mathrm{Zr}^{*}$ & 0.15 \\
\hline
\end{tabular}

*At least $0.015 \%$ of grain-refining elements present.

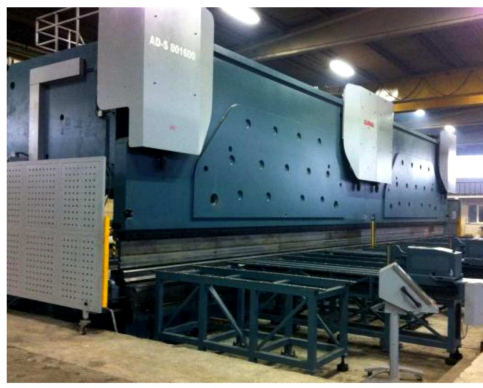

(a)

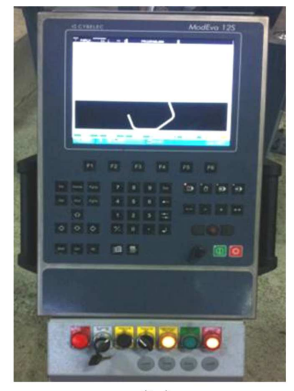

(b)

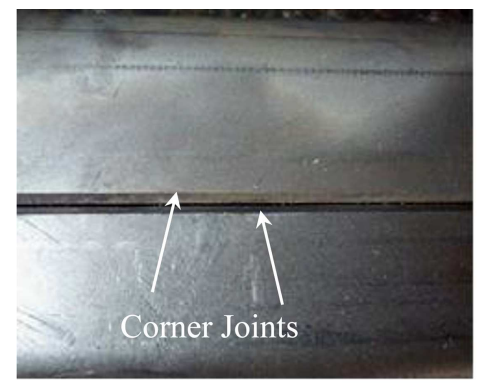

(a)

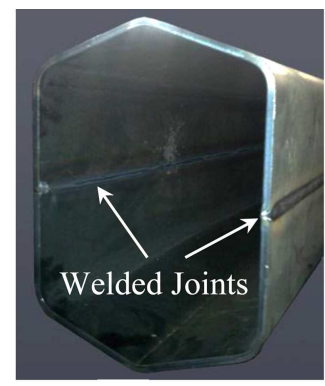

(b)
Figure 1. (a) Photos of the press brake used for boom bending step. (b) Control panel of the press brake.

lifting capacity, maximum boom extension length of $15 \mathrm{~m}$, and 6 boom extensions. For this example, quenched and tempered structural steel of S690QL plate is considered [23].

The properties of this material are summarized in Tables 2 and 3. As two steel pieces will be cut to form the boom, the values should be doubled to find the total energy consumption.

The required boom shape is achieved by pressing the plasma-cut pieces (Figure 1). In order to joint these two steel plates, two corner joints for each metal plate must be created at the boundaries. These corner joints are created using oxygen-acetylene cutting torch Figure 2(a). The shape and angle of the corner joints are the factors affecting the quality of the weld. The opening angle of the corner joints is chosen to be $45^{\circ}$ in order to ensure the best welding quality [24].

After the creation of corner joints, two steel pieces are welded together by an operator using gas metal arc welding Figure 2(b). The welding process done in this way takes very long time and the desired shape and size of the booms are difficult to obtain because of using
Figure 2. Traditional boom production: (a) Boom corner joints and (b) welded joints [25].

two steel pieces and the excessive deformation during manual welding. As the average length of the booms is a big number $3 \mathrm{~m}$, eliminating excessive deformations of the weld is impossible.

In the alternative boom design proposed in this work (patent pending), several energy consuming steps of the traditional boom manufacturing are eliminated. The details of the alternative design and the way to perform it are as follows: A single steel piece is plasmacut from the steel plate at first, which is large enough to form the boom shape after bending.

Table 4 lists the details of this cutting process, taking the same knuckle crane as that in the example. This single piece is again bent according to the size of the boom in the press brake Figure 3(a). However, after the bending process of the single metal sheet based on the boom shape, the corner joints are formed automatically as given in Figure 3(b). The corner joint creation steps are eliminated; the last step is to weld this single metal sheet to itself with a single welding process with the help of the welding manipulator designed and implemented in this study [25]. 
Table 4. The values of plate cutting for the booms obtained from a single piece.

\begin{tabular}{|c|c|c|c|c|c|c|}
\hline $\begin{array}{l}\text { Welded } \\
\text { booms }\end{array}$ & $\begin{array}{c}\text { Thickness } \\
(\mathbf{m m})\end{array}$ & $\begin{array}{l}\text { Width } \\
(\mathrm{mm})\end{array}$ & $\begin{array}{l}\text { Length } \\
(\mathrm{mm})\end{array}$ & $\begin{array}{c}\text { Plasma } \\
\text { speed } \\
(\mathrm{mm} / \mathrm{min})\end{array}$ & $\begin{array}{c}\text { Plasma } \\
\text { time* } \\
(\mathrm{s})\end{array}$ & $\begin{array}{c}\text { Consumption } \\
\text { energy** } \\
(\mathrm{kWh})\end{array}$ \\
\hline Knuckle boom & 10 & 1680 & 2650 & 2600 & 201 & 1,6750 \\
\hline 1. Extension & 10 & 1550 & 2750 & 2600 & 199 & 1,6593 \\
\hline 2. Extension & 10 & 1430 & 2850 & 2600 & 198 & 1,6510 \\
\hline 3. Extension & 10 & 1300 & 2950 & 2600 & 196 & 1,6334 \\
\hline 4. Extension & 8 & 1200 & 3050 & 3300 & 156 & 1,3010 \\
\hline 5. Extension & 8 & 1090 & 3150 & 3300 & 155 & 1,2917 \\
\hline 6. Extension & 8 & 1000 & 3250 & 3300 & 156 & 1,3010 \\
\hline \multicolumn{5}{|c|}{ Total (The values are doubled because there are two pieces) } & 1261 & 10,5124 \\
\hline
\end{tabular}

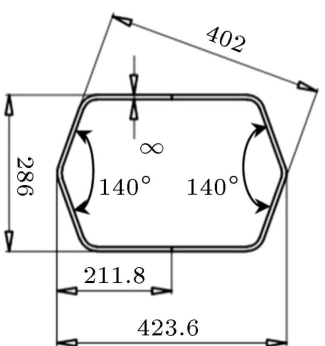

(a)

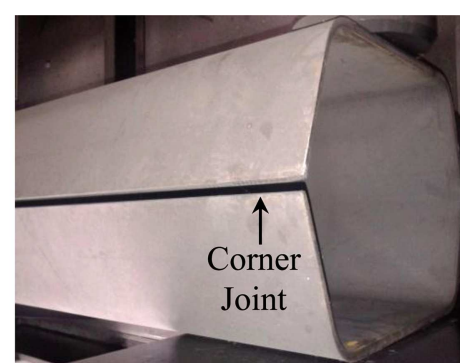

(b)
Figure 3. (a) Bending dimensions of the sample boom [25]. (b) Corner joint after bending.

As can be seen from Tables 1 and 4, the alternative design has two main advantages over the traditional method. First, the welding time and the consumed energy for the welding processes are reduced. Moreover, cutting the steel pieces from the steel plate will consume less energy and time. Second, the corner joint creation steps are completely eliminated; thus, the total energy consumption to manufacture the booms is reduced significantly.

\section{Design of the welding manipulator}

Due to two important reasons, a manipulator is designed during this study. First, as the booms will have a single welded line (the boom shape will not be $100 \%$ symmetric due to this welded side), this single welded line should be as high quality as possible. The quality of the welding performed by an operator will not be as good as that of the welding done by an automatic machine. Second, operators will not be exposed to the harmful gases generated during the welding operation. Furthermore, these gases can be filtered using related apparatus so that the environment protection is achieved. The block diagram of the system explained above is shown in Figure 4.

The MIG method chosen for the boom welding of this study is one of the most suitable arc welding methods as it is easy and cheap and does not leave any residues. The specifications of the MIG welding machine chosen for the welding process are given in Table 5. Similarly, Table 6 lists the technical specifications of the welding oscillator [18].

The flow diagram of the system operation is given in Figure 5. The operation of the system can be summarized simply as follows: Initially, the boom to be welded is fixed. The torch is brought to the starting point of welding. Two-axis movement control automation operates the torch. To achieve a high quality welding, it is best to use a constant speed. Welding current, welding wire, and wire feed speed are chosen according to the needs of the required welding

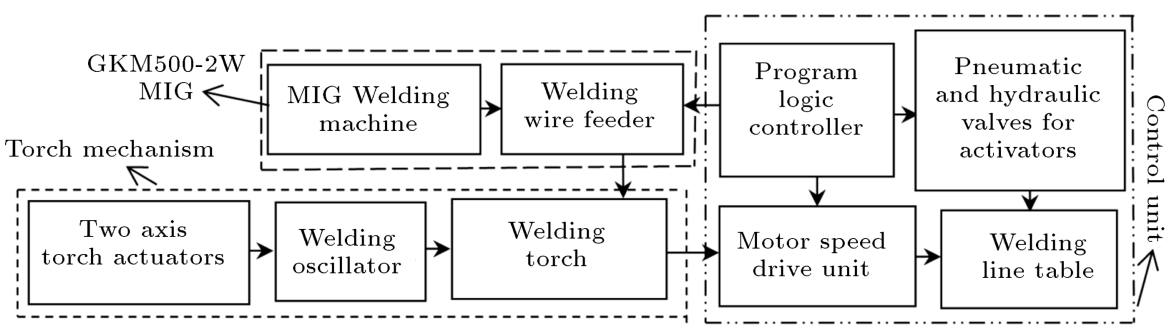

Figure 4. System configuration of welding manipulator. 
Table 5. Technical specifications of the GKM500-2W MIG arc welding machine [26].

\begin{tabular}{ll}
\hline \multicolumn{1}{c}{ Item } & \multicolumn{1}{c}{ Specifications } \\
\hline Input voltage & 3 phase, $380 \mathrm{~V}, 50-60 \mathrm{~Hz}$ \\
Power & $27.5 \mathrm{kVA}$ \\
Open circuit voltage & $16-57 \mathrm{~V}$ \\
Current range & $40 \mathrm{~A}-500 \mathrm{~A}$ \\
Duty cycle & $60 \%, 500 \mathrm{~A} ; 100 \%, 400 \mathrm{~A}$ \\
Protection class & $\mathrm{IP} 23$ \\
Wire feeder & $0.8,1,1.2,1.6$ \\
Wire type & Fe-Flux cored \\
\hline
\end{tabular}

Table 6. Technical specifications of the GKM $500-2 \mathrm{~W}$ MIG arc welding machine [26].

\begin{tabular}{ll}
\hline \multicolumn{1}{c}{ Item } & \multicolumn{1}{c}{ Specifications } \\
\hline Right width & Maximum $30 \mathrm{~mm}($ step $0.1 \mathrm{~mm})$ \\
Left width & Maximum $30 \mathrm{~mm}($ step $0.1 \mathrm{~mm})$ \\
Sweeping angle & $\pm 30^{\circ}$ \\
Left speed & $0 \sim 4 \mathrm{~m} / \mathrm{min}($ step $0.1 \mathrm{~m} / \mathrm{min})$ \\
Right speed & $0 \sim 4 \mathrm{~m} / \mathrm{min}($ step $0.1 \mathrm{~m} / \mathrm{min})$ \\
Stop time on the left & $0 \sim 6.0 \mathrm{~s}($ step $0.1 \mathrm{~s})$ \\
Stop time on the right & $0 \sim 6.0 \mathrm{~s}($ step $0.1 \mathrm{~s})$ \\
Stop time on the center $0 \sim 6.0 \mathrm{~s}($ step $0.1 \mathrm{~s})$
\end{tabular}

Table 7. Boom welding parameters depending on the thickness of the work-piece.

\begin{tabular}{lc}
\hline \multicolumn{1}{c}{ Item } & Specifications \\
\hline Thickness of the piece $(\mathrm{mm})$ & $10-8$ \\
& \\
The consumption rate of the & $19-17$ \\
wire feeder $(\mathrm{mm} / \mathrm{s})$ & \\
& \\
Welding speed $(\mathrm{mm} / \mathrm{s})$ & $4.5-7.5$ \\
Diameter of the wire $(\mathrm{mm})$ & $1.2-1.2$ \\
Used current $(\mathrm{A})$ & $280-230$ \\
Protective gas $\mathrm{CO}_{2}-\mathrm{Ar}(\mathrm{L} / \mathrm{min})$ & $16-15$ \\
\hline
\end{tabular}

process. Using a protective gas during the welding process is of great importance for the welding quality. During the welding process, the flow of the protective gas is controlled. The parameter of wire feeder speed is adjusted on the speed control unit. The selected welding parameters depending on the thickness of the boom are shown in Table 7 .

Figure 6 shows the designed welding manipulator and includes the initial prototype Figure 6(a), the final prototype Figure $6(\mathrm{~b})$, and the extra precautions taken to minimize the bending of the boom shape due to temperature variations after the welding Figure 6(c).

Figure 7 shows the sample welded booms using the designed welding manipulator; the first with very fast welding speed Figure 7(a); then, with fast welding

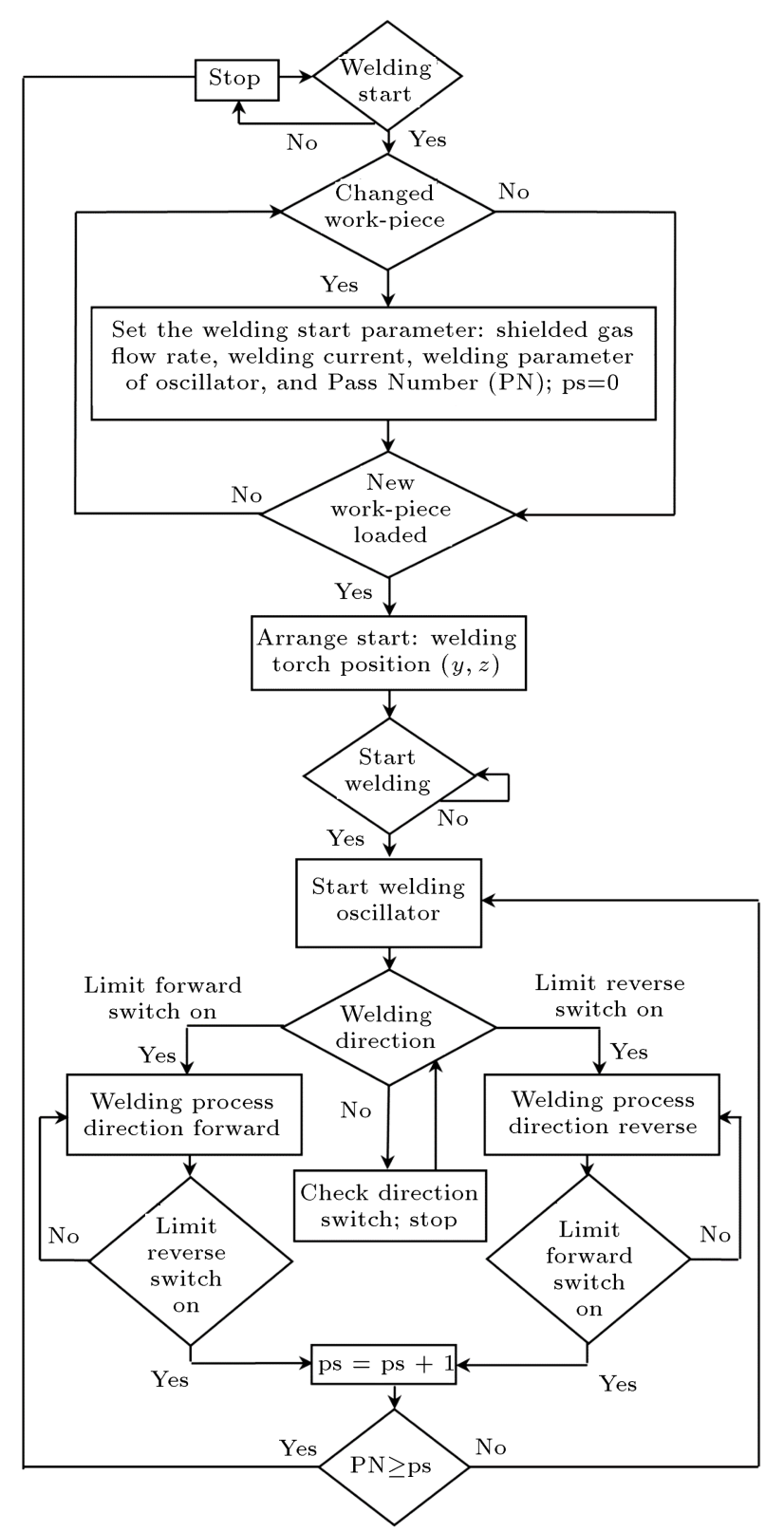

Figure 5. Flow diagram of welding manipulator.

speed Figure 7(b); and, finally, with the required welding speed Figure $7(\mathrm{c})$. These booms are welded under approximately 20 psi $\mathrm{Ar}$ and $\mathrm{CO}_{2}$ gases, which prevent oxidation problems. $8 \mathrm{~mm}$ thick pieces are welded using $390 \mathrm{~A}$ of current and $10 \mathrm{~mm}$ thick pieces are welded using 410 A of current with 3 passes. The welding operation is carried out in a closed and air filtered chamber to minimize the effects of the hazardous gases generated during the operation on the operators and the environment.

\section{Results and discussions}

Welding tests of boom samples designed and manufactured with the alternative method and the boom 


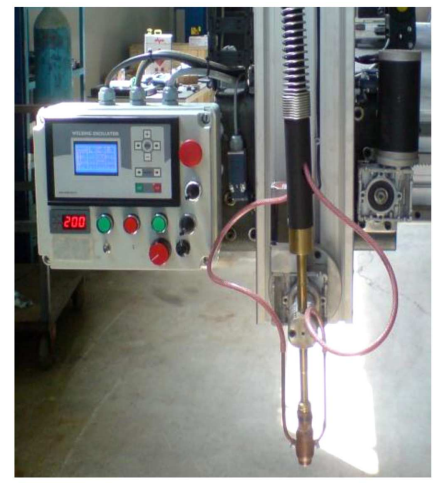

(a)

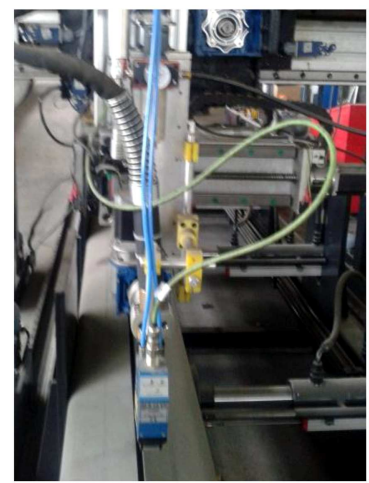

(b)

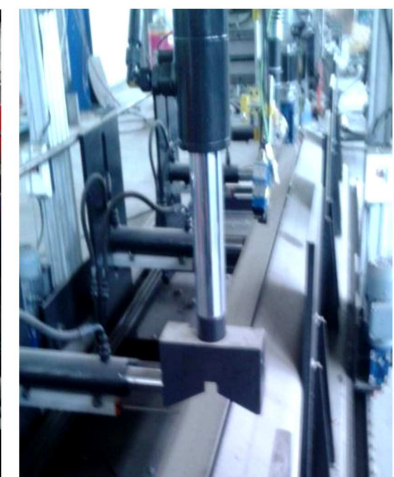

(c)

Figure 6. The implemented welding manipulator: a) Initial prototype, b) final prototype, and c) pressing corner joint of boom with hydraulic activator after welding process [25].

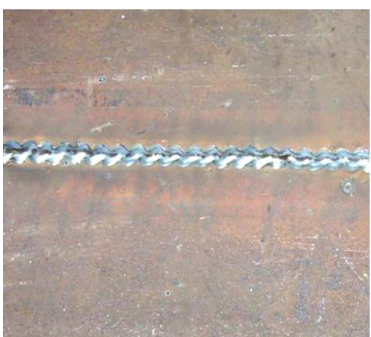

(a)

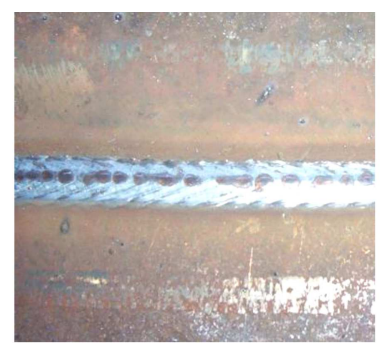

(b)

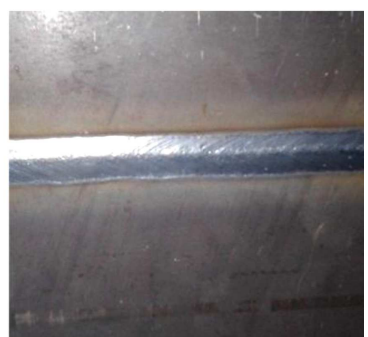

(c)

Figure 7. Three samples of welded booms using the designed welding manipulator: a) Very-high-speed welding, b) high-speed welding, and c) required-speed welding.

Table 8. Welding test tensile experiment.

\begin{tabular}{lcccc}
\hline Welding Type & Traditional & Traditional & Alternative & Alternative \\
\hline Max. load (Fm, kN) & 135.6 & 129.7 & 159.9 & 160.9 \\
Pulling tension (Rm, N/mm ${ }^{2}$ ) & 682 & 652 & 795 & 800 \\
Yield strength (Rt, N/mm ${ }^{2}$ ) & 497 & 513 & 602 & 605 \\
Elongation at break (A 5.65) & $8.75 \%$ & $6.125 \%$ & $14.37 \%$ & $13.89 \%$ \\
\hline \multirow{2}{*}{ Result } & Break has been observed & Break has been observed \\
& at the welding zone. & out of the welding zone. \\
\hline
\end{tabular}

samples with the traditional design and manufacturing method are made in the laboratory of KOSGEB in our region, and test results are given in Table 8 . Tests were done in accordance with TS EN ISO 6892-1 [27]. Sizes of the sample booms were also in accordance with the test protocol as follows: thickness (a) $7.95 \mathrm{~mm}$, width (b) $25.0 \mathrm{~mm}$, cross-section (So) $198.8 \mathrm{~mm}^{2}$, body length (Lc) $80.0 \mathrm{~mm}$, first measuring length (Lo) $80.0 \mathrm{~mm}$, and last measuring length $(\mathrm{Lu}) 87.0 \mathrm{~mm}$. Tests were done with DARTEC brand M9000 Model $600 \mathrm{kN}$ universal testing machine according to TS EN ISO 6892-1 [27]. As seen from the test results in Table 8 , the performance of the alternative boom design and manufacturing method proposed in this study is better than that of the traditional boom design and manufacturing method. Hence, in addition to the energy saving advantages and minimizing the risks of the hazardous gases on operators and the environment, the proposed alternative design and manufacturing method provide booms with better performance for mobile cranes.

Table 9 summarizes the energy consumption aspects of the traditional method and the proposed alternative method. As a result of the interpretation of the calculated data in Table 9, cutting the boom plates in plasma as a single piece instead of two pieces leads to an average of $41 \%$ less energy and time; moreover, welding the piece consumes approximately $53 \%$ less energy, time, and material. Hence, an optimized boom manufacturing process is achieved, which minimizes the use of manpower, energy, and material.

\section{Conclusion}

An optimized high quality boom manufacturing process is achieved, which minimizes the use of manpower, 
Table 9. Comparison of the conventional and the new boom manufacturing methods [25].

\begin{tabular}{|c|c|c|c|c|c|c|}
\hline \multirow{2}{*}{$\begin{array}{l}\text { Welded } \\
\text { Booms }\end{array}$} & \multicolumn{3}{|c|}{$\begin{array}{l}\text { Conventional boom } \\
\text { production method }\end{array}$} & \multicolumn{2}{|c|}{$\begin{array}{l}\text { New boom } \\
\text { production method }\end{array}$} & \multirow[b]{2}{*}{$\begin{array}{c}\text { Used } \\
\text { welding } \\
\text { wire }(\mathrm{m})\end{array}$} \\
\hline & $\begin{array}{l}\text { Welding } \\
\text { time (s) }\end{array}$ & $\begin{array}{c}\text { Welding energy } \\
\text { consumption } \\
(\mathrm{Kwh})\end{array}$ & $\begin{array}{c}\text { Used } \\
\text { welding } \\
\text { wire }(\mathbf{m}) \\
\end{array}$ & $\begin{array}{l}\text { Welding } \\
\text { time (s) }\end{array}$ & $\begin{array}{c}\text { Welding energy } \\
\text { consumption } \\
(\mathrm{Kwh})\end{array}$ & \\
\hline Knuckle & 1930 & 9.65 & 185 & 900 & 4.500 & 92 \\
\hline 1.extension & 2010 & 10.0503 & 196 & 940 & 4.700 & 95 \\
\hline 2.extension & 2080 & 10.4004 & 206 & 975 & 4.875 & 98 \\
\hline 3.extension & 2150 & 10.7502 & 209 & 1005 & 5.025 & 102 \\
\hline 4.extension & 1526 & 7.2061 & 135 & 713 & 3.3669 & 65 \\
\hline 5.extension & 1576 & 7.4422 & 147 & 735 & 3.4708 & 67 \\
\hline 6.extension & 1630 & 7.6972 & 145 & 762 & 3.5983 & 70 \\
\hline Total & 12902 & 63.1964 & 1223 & 6030 & 29.5361 & 589 \\
\hline
\end{tabular}

energy, and material. It is shown that the energy and time required during the plasma-cutting process of boom parts are decreased by about $41 \%$, and the energy consumption during the welding process is decreased by about $53 \%$ compared to the traditional methods. Thus, $41 \%$ savings can be achieved with the proposed method.

For further studies, this paper will provide a guide to the related industry to consider their production line, as significant amounts of energy, manpower, and material usage can be saved with alternative design and manufacturing methods. In Konya, which is one of the most important centers regarding mobile crane manufacturing in Turkey, approximately, $49 \mathrm{MWh}$ energy can be saved and 49 ton $\mathrm{CO}_{2}$ gas release to the environment can be prevented in the welding and cutting processes annually. Material and manpower savings as well as minimizing hazardous gas production will increase the importance of this study. This study is an example which shows that industry can create such alternative production methods to minimize the production of hazardous gases and the consumed energy in order to control and minimize the global warming issue.

\section{Acknowledgment}

This study was supported by TUBǏTAK 1501 - Project number 3090646 in the mobile crane industry with the capacity of 120 tons and 3 meters by Necmettin Erbakan University Scientific Research Projects Office.

\section{References}

1. Florides, G.A. and Christodoulides, P. "Global warming and carbon dioxide through sciences", Environment International, 35(2), pp. 390-401 (2009).

2. Güvenç, U., Sönmez, Y., Duman, S. and Yörükeren N.
"Combined economic and emission dispatch solution using gravitational search algorithm", Scientia Iranica, 19(6), pp. 1754-1762

3. Yousefi, M., Khoramivafa, M. and Mondani, F. "Integrated evaluation of energy use, greenhouse gas emissions and global warming potential for sugar beet (Beta vulgaris) agroecosystems in Iran", Atmospheric Environment, 92, pp. 501-505 (2014).

4. Winter, R.A. "Innovation and the dynamics of global warming", Journal of Environmental Economics and Management, 68(1), pp. 124-140 (2014).

5. Nejat, P., Jomehzadeh, F., Taheri, M.M., Gohari, M. and Majid, M.Z.A. "A global review of energy consumption, $\mathrm{CO}_{2}$ emissions and policy in the residential sector (with an overview of the top ten $\mathrm{CO}_{2}$ emitting countries)", Renewable and Sustainable Energy Reviews, 43, pp. 843-862 (2015).

6. Akorede, M.F., Hizam, H., Ab Kadir, M.Z.A., Aris, I. and Buba, S.D. "Mitigating the anthropogenic global warming in the electric power industry", Renewable and Sustainable Energy Reviews, 16(5), pp. 2747-2761 (2012).

7. Yuksel, I. "Global warming and environmental benefits of hydroelectric for sustainable energy in Turkey", Renewable and Sustainable Energy Reviews, 16(6), pp. 3816-3825 (2012).

8. Anisura, M.R., Mahfuza, M.H., Kibriaa, M.A. and Saidura, R. "Curbing global warming with phase change materials for energy storage", Renewable and Sustainable Energy Reviews, 18, pp. 23-30 (2013).

9. Shrivastava, A., Krones, M. and Pfefferkorn, F.E. "Comparison of energy consumption and environmental impact of friction stir welding and gas metal arc welding for aluminum", CIRP Journal of Manufacturing Science and Technology, 9, pp. 159-168 (2015).

10. Mose, C. and Weinert, N. "Process chain evaluation for an overall optimization of energy efficiency in manufacturing-The welding case", Robotics and 
Computer-Integrated Manufacturing, 34, pp. 44-51 (2015).

11. Kim, I.S., Son, J.S. and Yarlagadda, P.K.D.V. "A study on the quality improvement of robotic GMA welding process", Robotics and Computer-Integrated Manufacturing, 19(6), pp. 567-572 (2003).

12. Guen, E.L., Fabbro, R., Carin, M., Coste, F. and Masson, P.L. "Analysis of hybrid Nd:YAG laser-MAG arc welding processes", Optics \& Laser Technology, 43(7), pp. 1155-1166 (2011).

13. Gua, X., Lia, H., Yanga, L. and Gaob, Y. "Coupling mechanism of laser and arcs of laser twin-arc hybrid welding and its effect on welding process", Optics \& Laser Technology, 48, pp. 246-253 (2013).

14. Sidhar, H., Martinez, N.Y., Mishra, R.S. and Silvanus, J. "Friction stir welding of Al-Mg-Li 1424 alloy", Materials \& Design, 106, pp. 146-152 (2016).

15. Wu, L., Cheon, J., Kiran, D.V. and Na, S. "CFD simulations of GMA welding of horizontal fillet joints based on coordinate rotation of arc models", Journal of Materials Processing Technology, 231, pp. 221-238 (2016).

16. Tarakçioğlu, N. and Özcan, M. Lasers and Material Processing Application 1st ed. pp. 179-200, Atlas Press, Istanbul, Turkey (2004).

17. Vural, M. "Welding processes and technologies", Reference Module in Materials Science and Materials Engineering Comprehensive Materials Processing, 6, pp. 3-48 (2014).

18. Özcan, M. "Design and realization of a welding oscillator" , Turk. J. Elec. Eng. \& Comp. Sci., 22, pp. 1219-1229 (2014).

19. Erden, M.S. and Maric', B. "Assisting manual welding with robot", Robotics and Computer-Integrated Manufacturing, 27(4), pp. 818-828 (2011).

20. Kim, I.S., Son, J.S., Lee, S.H. and Yarlagadda, P.K.D.V. "Optimal design of neural networks for control in robotic arc welding", Robotics and ComputerIntegrated Manufacturing 20(1), pp. 57-63 (2004).

21. Hong, T.S., Ghobakhloo, M. and Khaksar, W. "Robotic welding technology", Reference Module in Materials Science and Materials Engineering from Comprehensive Materials Processing, 6, pp. 77-99 (2014).

22. Popovic', O., Cvetkovic'a, R.P., Burzic', M., Lukic', U. and Beljic', B. "Fume and gas emission during arc welding: Hazards and recommendation", Renewable and Sustainable Energy Reviews, 37, pp. 509-516 (2014).

23. http://www.masteel.co.uk/s690-ql.htm Accessed: December (2015).
24. Unt, A., Poutiainen, I. and Salminen, A., "Influence of filler wire feed rate in laser-arc hybrid welding of Tbutt Joint in shipbuilding steel with different optical setups", Physics Procedia (15th Nordic Laser Materials Process. Conf., Nolamp 15), 78, pp. 45-52 (2015).

25. Özcan, M., Endiz, M.S. and Alver, V., "A new approach to the boom welding technique by determining seam profile tracking", Int'l Journal of Advances in Mechanical \& Automobile Engg. (IJAMAE), 2(1), pp. 31-34 (2015).

26. Gedikwelding, http://www.gedikwelding.com/product/ gkm- 500-2w-welding-machines, Accessed: March, (2016).

27. Standart of TS EN ISO 6892-1 "Metallic Materials for Tensile Testing" (2011).

\section{Biographies}

Muciz Özcan was born in Konya, Turkey, in 1966. He received the BS degree from Anadolu University, Eskisehir, Turkey, in 1989; the MS and PhD degrees from Selçuk University, Konya, Turkey, in 1996 and 2003, respectively. He is currently associate professor in the Electrical and Electronics Engineering Department of Necmettin Erbakan University, Turkey. His research interests include automation, electrical machines, sensors, laser electronics, and energy efficiency. He is the author or co-author of several papers published in scientific journals or conference proceedings.

Mustafa Yağci was born in Konya, Turkey, in 1963. He received the BS degree from Marmara University, Istanbul, Turkey, in 1984; the MS degree from Gazi University, Ankara, Turkey, in 1994; and the PhD degree from Selçuk University, Konya, Turkey, in 2005. He is currently Assistant Professor in the Electrical and Electronics Engineering Department of Necmettin Erbakan University, Turkey. His research interests include electrical machines and driving circuits, harmonics of transformers, power electronics, and photovoltaic power plants. He is the author or co-author of several papers published in scientific journals or conference proceedings.

Veysel Alver was born in Antalya, Turkey, in 1976. He received the BS and Ms degrees from Selçuk University, Konya, Turkey, in 1998 and 2012, respectively. $\mathrm{He}$ is research engineer in MPG Machinery Production Group Inc. Co. His research interests include production of knuckle boom mobile cranes, telescopic boom mobile cranes, tree trans planters, etc. 